University of Nebraska - Lincoln

DigitalCommons@University of Nebraska - Lincoln

Faculty Publications in Educational

Administration

Educational Administration, Department of

Fall 2020

\title{
Principals' Schema: Leadership Philosophies and Instructional Leadership
}

Sarah J. Zuckerman

University of Nebraska - Lincoln, szuckerman2@unl.edu

Cailen O'Shea

North Dakota State University--Fargo, Cailen.Oshea@ndsu.edu

Follow this and additional works at: https://digitalcommons.unl.edu/cehsedadfacpub

Part of the Educational Administration and Supervision Commons

Zuckerman, Sarah J. and O'Shea, Cailen, "Principals' Schema: Leadership Philosophies and Instructional Leadership" (2020). Faculty Publications in Educational Administration. 123.

https://digitalcommons.unl.edu/cehsedadfacpub/123

This Article is brought to you for free and open access by the Educational Administration, Department of at DigitalCommons@University of Nebraska - Lincoln. It has been accepted for inclusion in Faculty Publications in Educational Administration by an authorized administrator of DigitalCommons@University of Nebraska - Lincoln. 


\title{
Principals' Schema: Leadership Philosophies and Instructional Leadership
}

\author{
Sarah J. Zuckerman ${ }^{1}$ and Cailen O'Shea ${ }^{2}$
}

\author{
1 University of Nebraska-Lincoln, Lincoln, NE \\ 2 North Dakota State University, Fargo, ND \\ Corresponding author: Sarah J. Zuckerman, University of Nebraska-Lincoln, \\ 132 Teachers Hall, Lincoln, NE 68588, USA. Email szuckerman2@unl.edu \\ ORCID Sarah J. Zuckerman https://orcid.org/oooo-0002-3330-6431
}

\begin{abstract}
The Every Child Succeeds Act of 2015 signaled a shift toward the recognition of the importance of school leadership, reflecting a growing body of literature that demonstrates principals are second only to classroom instruction in supporting student success. This influence is the greatest when principals focus on teaching and learning, or instructional leadership. The ability to focus on instructional leadership requires knowledge, as well as the schema that creates mental models for instructional leadership tasks. This study draws on interviews with principals to examine the relationship between their theory of leadership, which are conceptualized as leadership schema, and their instructional leadership practices. The findings suggest that there are similarities in the instructional leadership tasks undertaken by principals, but that how they engage in tasks is partially determined by their theory of leadership.
\end{abstract}

Keywords: school leadership, instructional leadership, qualitative inquiry

Published in Journal of School Leadership, 2020, 23p.

doi:10.1177/1052684620966063

Copyright (C) 2020 Sarah J. Zuckerman and Cailen O’Shea. Published by SAGE Publications. Used by permission. 
$\mathrm{T}$ The inclusion of flexible Title II-A funds for school leadership in the Every Child Succeeds Act (ESSA) signaled a policy shift toward recognizing the importance of effective leadership, second only to classroom teaching, in student success (Leithwood et al., 2004). However, school leaders often play indirect roles in student achievement by getting the conditions right for learning through school climate, supporting teacher leadership, and student and family engagement (Leithwood et al., 2008).

Among these many pathways, school leaders' focus on teaching and learning provides the greatest influence on student learning (Robinson et al., 2008). This focus, often referred to as instructional leadership, includes a variety of leadership tasks such as defining the school's mission, managing the instructional program, and promoting a positive learning climate (Hallinger \& Murphy, 1985). Leaders' ability to carry out these tasks assumes several precursors: principals' knowledge of teaching and learning; principals' ability to attend to instructional leadership tasks, as opposed to building management and student discipline; and principals' ability to balance the expectations of many stakeholders in the face of constant, evolving demands (Hallinger \& Murphy, 2013; McBrayer et al., 2018; Metz et al., 2019). Despite the ubiquitous expectations for instructional leadership, there remains a gap between expectations and practice (Hallinger et al., 2020; Shaked, 2018).

Attempts have been made to understand this gap. In doing so, we turn to the leadership literature, which suggests leaders' ability to engage in particular leadership tasks depends on their perception of goals, sense of self-efficacy, and their task schema. Task schema represents scripts, or mental models that contain leaders' knowledge and implicit theories of leadership, which in turn lead to their selection of strategies and enactment of leadership behaviors (McCormick \& Martinko, 2004). In this study, we examine how principals' theories of leadership, or schema representing what it means to be a "good leader," might inform their selection of instructional leadership strategies and their enactment of instructional leadership behaviors. This secondary analysis derived from a larger mixed-methods study conducted to provide information on principals and their working conditions for the State Department of Education and its ESSA Leadership Learning Community (ELLC), part of a Wallace Foundation initiative. 
It is guided by two research questions: (a) How do principals describe their theory of leadership? and (b) How do these theories serve as a schema for their instructional leadership?

\section{Literature Review}

In this section, we review the organizational and educational literature that aligns with the most prevalent theories of leadership identified in our data: relational leadership, leading by example, distributed leadership, servant leadership, and facilitative leadership.

\section{Relational Leadership}

In the organizational literature, relational leadership focuses on social influence through reciprocal respect, trust, loyalty, and support to generate buy-in for change, which can be understood as consensus, motivation, and inspiration of individuals to identify with shared goals (Brower et al., 200o). The development of trust fosters safe spaces for risk-taking and creativity that can support behavior changes (Baard et al., 2014; Martin et al., 2016; Qu et al., 2015). Mutual trust increases job satisfaction, commitment, and citizenship within the organization (Brower et al., 2000). Additionally, relational leaders use social networks to create shared agendas for change by engaging in dialogue with others to make sense of complex issues, solve problems, and shape the strategic directions and practical actions to support collaborative action. This work is inherently affective, with relational leaders demonstrating empathy, appreciation of others, and encouragement (Cunliffe \& Eriksen, 2011). Relational leadership shifts from heroic and hierarchical models toward leadership that emphasizes collaboration, social interactions, networks of influence, empathy, and trust (Fletcher \& Kaeufer, 2003).

Although the educational research on relational leadership is slim, like the organizational literature, it identifies trust and relationships as key elements that support indirect influence on instruction by building teacher will and school improvement through collective decision-making, suitability of reform efforts, and their implementation (Louis et al., 2010, 2016; Reitzug et al., 2008). Relationships 
support organizational learning and the improvement of student learning (Louis et al., 2010, 2016). Teacher trust of principals positively correlates with student achievement, and reciprocal trust facilitates the implementation of innovation, lubricates instructional feedback, and contributes to a shared sense of responsibility for collective goals (Zuckerman et al., 2017; Lawson et al., 2017; Tschannen-Moran \& Gareis, 2015). Beyond trust, affective relationships between principals and teachers support teacher job satisfaction and positive school climate (Price, 2012, 2015). On the basis of the literature and the empirical data, we operationalized relational leadership as engaging in trusting relationships with teachers in a way that emphasizes motivation, inspiration, and shared ownership of goals to improve educational outcomes.

\section{Leading by Example}

In the organizational literature, leading by example is seen as an improvement strategy (Boiral et al., 2015; Yin \& Schmeidler, 2009). The work of leaders can be seen as ceremonial and superficial; however, leading by example sets a precedent of significance by demonstrating commitment (Boiral et al., 2015). Integrity provides additional motivation by fostering trust and creating an alignment between the leader's recommendations and actions (Eisenkopf, 2020).

In educational literature, there is limited discussion of leading by example. Principals who lead by example model instructional, personal, and other behaviors as a means to guide school improvement and provide vicarious learning opportunities for teachers. These opportunities allow teachers to see and hear behaviors, allowing for adaptation and reconstruction of previously held knowledge through first-hand exposure and demonstration (Beattie, 2002; Versland \& Erickson, 2017). Modeling and mentoring facilitate the growth of others, which in turn can support a sense of comradery when the leader works alongside teachers (Beattie, 2002; Versland \& Erickson, 2017). Such leadership supports the mission of the school by inspiring teachers to emulate the principal's actions and efforts (Versland \& Erickson, 2017). Leading by example supports teacher self-efficacy, which contributes to student learning (Louis et al., 2010; Versland \& Erickson, 
2017). For this study, we operationalized the leadership theory of leading by example as principals who model instructional, interpersonal, and other behaviors as a means to communicate expectations and guide teachers for school improvement.

\section{Distributed Leadership}

In the organizational literature, Bolden (2011) provides a review of distributed leadership, noting it has gained favor as a "post-heroic" form of leadership, shifting the focus from traits to behaviors. However, the research on distributed leadership in organizations derives largely from education (Bolden, 2011), and thus we focus our attention on there. Definitions of distributed leadership in education focus on the stretching, sharing, and spreading of leadership actions across many individuals in both formal and informal decision-making roles throughout the school (Harris et al., 2007; Smylie et al., 2007). The stretching of instructional leadership provides greater opportunities for principals and others to increase the instructional capacity of teachers (Harris, 2008; Klar, 2012). Distributed leadership is social and relational, occurring within the interactions of individuals (Spillane et al., 2004), with the establishment of trust combined with opportunities to learn support instructional competency (Lawson et al., 2017).

Additionally, the creation of spaces for teacher collaboration contributes to social learning to build individual and collective capacity (Fullan \& Quinn, 2016; Leithwood \& Azah, 2017). The shared decision-making component of distributed leadership models supports teacher commitment for change (Supovitz \& Tognatta, 2013). Distributed instructional leadership has shown to support instructional improvement and has been identified as a lever for school improvement (e.g., Day et al., 2011; Leithwood, 2016). Likewise, distributed leadership creates a tighter coupling between leadership and instructional practices (Spillane \& Burch, 2006; Spillane et al., 2004). The distribution of instructional leadership roles across school leaders, coaches, and teachers, paired with routines for goal setting, instructional feedback, and professional development, and relational trust develops the capacity of schools to engage in change, such as integration of new standards into curriculum and instruction (Lawson et al., 2017). For 
this study, we operationalize distributed leadership as a principal intentionally spreading leadership tasks, particularly those around improving instruction, to teachers and others.

\section{Servant Leadership}

"Servant leadership" was first used in the organizational literature to describe leadership that prioritizes meeting the needs of others and focusing on their wellbeing and growth (Greenleaf, 1970; Van Dierendonck, 2011). From a recent review of the literature, Eva et al. (2019) focus on the motivation, mode and mindset in their definition of servant leadership "an (1) other-oriented approach to leadership (2) manifested through one-on-one prioritizing of follower individual needs and interests, (3) and outward reorienting of their concern for self toward concern for others within the organization and the larger community" (p. 114). This definition moves beyond earlier work that identified lists of attributes and of servant leaders (e.g., Barbuto \& Wheeler, 2006; Russell \& Stone, 2002; Spears, 2010). Eva and colleagues (2019) suggest that when leaders focus on supporting followers in reaching their full potential, individuals become empowered to take on tasks and decision-making on their own, as well as creating a culture of communal sharing and serving others.

Such a conception of servant leadership fits with attempts in educational leadership to move beyond a single heroic leader and to create shared leadership in schools by enhancing the willingness of others to engage in leadership activities. This suggests servant leadership as a mechanism to support the distribution of instructional leadership roles, routines, and relationships that support school change efforts (Zuckerman et al., 2017; Lacroix \& Verdorfer, 2017). Other research on servant leadership has tried to draw a statistical relationships between principals' behavior and outcomes such as school climate, student achievement, and teacher job satisfaction, with mixed results (Black, 2010; Cunningham, 2008; Shaw \& Newton, 2014). Drawing largely on the organizational literature and our data, we operationalized servant leadership as principals placing interests of others above their own, meeting the needs of teachers, developing and empowering others, and communicating a vision to recruit others to it. 


\section{Facilitative Leadership}

In the organizational literature, Watt (2009) described facilitative leadership as an inherently social and people-centered approach to meeting goals through effective relational processes. Facilitative leaders attempt to promote innovative thinking among their staff and recognizes the value of learning from trial and error. They are willing to take risks to promote positive change to meet demands from the internal or external environments. Effective facilitative leaders continually seek to empower followers to meet the challenges that arise due to changes or shifts in their internal culture and external environment (Watt, 2009).

In the educational literature, attention to facilitative leadership originates in early studies of school improvement (e.g., Hord, 1992). Facilitative leadership in schools relies on effective relationships and risk-taking, by demonstrating trust in teachers and encouraging creativity; providing autonomy for teachers to use professional judgment; and providing resources, materials, and professional development to try new things (Blase \& Blase, 1996; Hord, 1992). Facilitative leaders provide data and technical assistance to teachers to support collective decision-making and change efforts within shared governance structures (Blase \& Blase, 1996; Hord, 1992). Such leaders also seek out and value teacher input. Facilitative leaders support teacher affective states and professional engagement that increase motivation, ownership, satisfaction, selfefficacy, and a sense of professionalism. In addition to facilitative strategies, Blase and Blase (1996) identify personality traits such as caring, enthusiasm, optimism, honesty, and friendliness, framing leadership as an intrinsic characteristic. Given the rise of distributed leadership models in the 2ooos, facilitative leadership in education appears to have lost currency in the educational literature. However, we include it as a separate category as principals in our study specifically described themselves as facilitative leaders. Our definition of facilitative leadership focuses on the actions of school leaders to provide others with the opportunities and the capacity to engage in leadership activities. 


\section{Instructional Leadership}

Instructional leadership has a long history in educational research, going back 50 years to the effective school movement. Early research tended to frame instructional leadership as a trait based, heroic form of leadership (Elmore, 2000; Heck et al., 1990; Neumerski, 2013). More recent research tends to list behaviors and actions, such as developing a vision for learning, nurturing a learning-focused culture, setting clear expectations, managing an effective learning environment, providing professional development and peer support networks, without attending to the processes behind them (Neumerski, 2013; Urick, 2016).

Research has shown that while indirect, principals' focus on teaching and learning has the greatest impact on student outcomes, such as principal feedback to teachers that can increase teacher confidence and self-efficacy (Leithwood et al., 2004; Mireles- Rios \& Becchio, 2018; Robinson et al., 2008). Principals also play key roles in building the instructional capacity of others to support school improvement (Neumerski, 2013; Wahlstrom \& Louis, 2008). Such a distributed view of instructional leadership (Spillane et al., 2004) examines the practice of all who engage in such leadership. Despite the importance of instructional leadership, research suggests principals spend little time directly engaged in the improvement of instruction (Grissom et al., 2013). In part, this is due to differences in how principals understand the purpose of schooling and suggests that principals' leadership activities are driven by their belief systems and mental maps (Shaked, 2018). Understanding why school leaders do or do not engage in instructional leadership tasks is an important question given that time spent on instructional leadership increases principals' self-efficacy and the influence of instructional leadership on student learning (McBrayer et al., 2018; Robinson et al., 2008).

\section{Framework}

Questions remain in the field of school leadership about what mechanisms guide principals' actions and the gap between the importance of instructional leadership and the limited efforts of principals to engage 
in these tasks (Grissom et al., 2013; Shaked, 2018). To advance this knowledge, this study was guided by a modified model of social cognitive theories of leadership (Figure 1) developed by McCormick and Martinko (2004). We selected this framework due to overlaps with important aspects of school leadership, such as direction setting, selfefficacy, and the role principals play in getting the conditions right for teaching and learning (Zuckerman et al., 2017; Leithwood et al., 2008; McBrayer et al., 2018).

McCormick and Martinko (2004) used a combination of social cognition and causal reasoning to explain differences in leadership. They define social cognition as the reciprocal relationship between an individual's social cognition, the behavior of an individual, and the social context in which they occur. They focus on leaders' self-control over their thoughts, behaviors, motivations, and emotions. To this self-regulation model of social cognition, McCormick and Martinko (2004) add causal reasoning or patterns of thinking about success and failure and how these patterns affect three key areas of leadership. Causal reasoning impacts leaders' perceptions of goals, which Shaked (2018) suggests influences the degree to which principals engage in instructional leadership tasks. Causal reasoning, or their attribution of cause and effect to outcomes of efforts (Graham, 1991), also influences leaders' self-efficacy or the confidence in one's ability to act on those goals. Causal reasoning influences leadership schema, which here represents a domain-specific understanding of one's abilities (Cross \& Markus, 1994; McCormick \& Martinko, 2004).

We theorize leadership task schema as a factor in driving leadership strategies and behavior. We focus on the implicit models and theories about what contributes to "good" leadership that principals develop through training and their experiences. This notion of schema aligns with Senge's (2006) conceptions of mental models, which derive from individuals' experiences, knowledge, and observations shape leadership practices (Kellar \& Slayton, 2016). In turn, goals, self-efficacy, and task schema influence the selection of leadership strategies and how those strategies shape leadership behavior (McCormick \& Martinko, 2004). In particular, we are interested in the strategies, behaviors and tasks principals reported in providing instructional support to teachers and how they communicate instructional goals. 


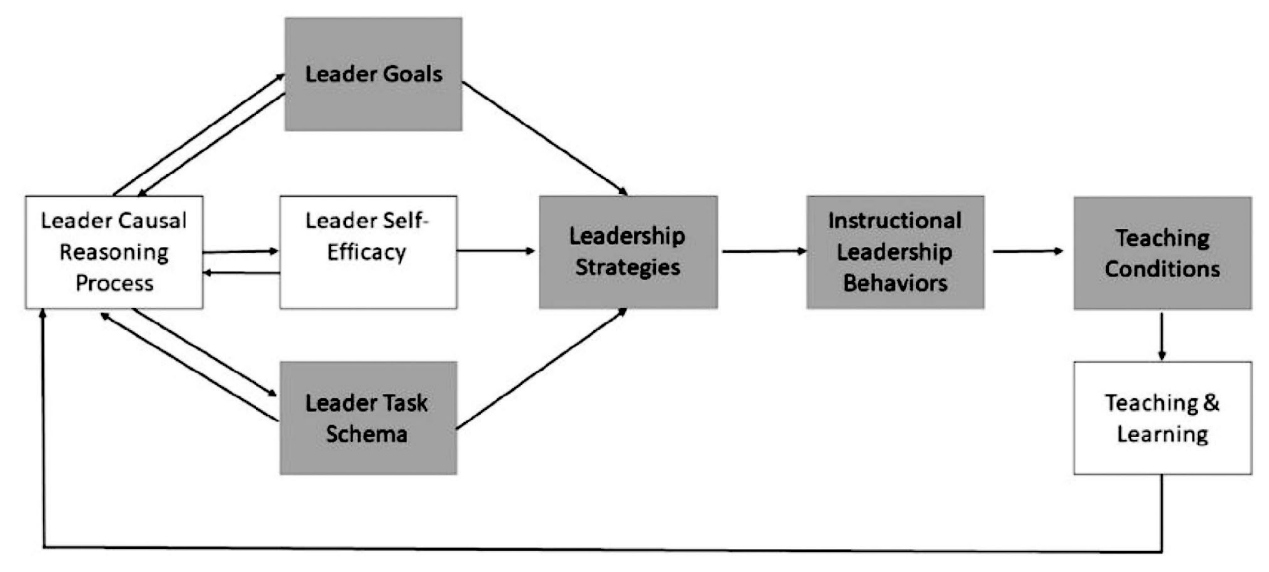

Figure 1. Cognitive model of leadership. Adapted from McCormick \& Martinko, 2004 .

\section{Methods}

The qualitative data used in this study were collected as part of a larger mixed-methods study conducted for a state department of education as part of their ESSA school leader efforts.

\section{Sample}

To select principals for this study, we used a list of principal contacts provided by the state Department of Education (DOE). To this, we added accountability ratings, geographic region, urbanicity, enrollment, and student demographics using the DOE's website and the National Center of Educational Statistics. We narrowed the population to schools with free and reduced priced lunch (FRPL) rates above the state average (40\%), which was used as a proxy for student poverty rates (Entwisle \& Astone, 1994). As many principals in the state work in a handful of metro districts, rural schools were oversampled to get a better sense of principals' work in a wider range of districts. For each region, we identified a subset of principals in each accountability rating. This resulted in a list of 56 principals whom we recruited by phone and email. A total of 21 principals agreed to participate, and Table 1 presents their school pseudonym, school characteristics, and their expressed leadership style(s). Numbers are rounded to protect the identity of principals. Two recruitment challenges were 
Table 1. Interview Participants.

\begin{tabular}{|c|c|c|c|c|c|c|c|}
\hline Pseudonym & Region & Locale & Enrollment & $\begin{array}{c}\text { ESSA } \\
\text { Rating }\end{array}$ & $\begin{array}{c}\text { FRPL } \\
\%\end{array}$ & $\begin{array}{c}\text { Minority } \\
\%\end{array}$ & Leadership Style \\
\hline Mt. View ES & Northeast & $\mathrm{RD}$ & 200 & 2 & $40 \%$ & $10 \%$ & Facilitative \\
\hline Bernard HS & Northeast & $\mathrm{CL}$ & 1400 & 1 & $80 \%$ & $80 \%$ & Relational, Distributed \\
\hline Jefferson MS & Northeast & $\mathrm{CL}$ & 600 & 1 & $90 \%$ & $80 \%$ & Relational, Distributed \\
\hline Eastside HS & Northeast & $C L$ & 1700 & 1 & $70 \%$ & $60 \%$ & Servant \\
\hline River View ES & Northeast & $\mathrm{RR}$ & 120 & 1 & $80 \%$ & $70 \%$ & Facilitative, Distributed \\
\hline Clark City MS & Northeast & SM & 800 & 3 & $70 \%$ & $80 \%$ & Relational, Distributed \\
\hline Fairmont ES & Southeast & CL & 270 & 1 & $70 \%$ & $90 \%$ & Relational, Facilitative, Modeling \\
\hline Erickson HS & Southeast & CL & 2000 & 3 & $30 \%$ & $20 \%$ & Servant, Modeling \\
\hline Carleton ES & Southeast & $\mathrm{RD}$ & 140 & 3 & $70 \%$ & $40 \%$ & Facilitative \\
\hline Smith ES & Southeast & $\mathrm{CL}$ & 390 & 2 & $80 \%$ & $80 \%$ & Relational, Facilitative, Servant \\
\hline Green Lake ES & Southeast & $\mathrm{RR}$ & 160 & 1 & $60 \%$ & $10 \%$ & Relational \\
\hline Oak Springs ES & Central & CS & 120 & 3 & $60 \%$ & $40 \%$ & Modeling, \\
\hline Midway ES & Central & TR & 400 & 1 & $60 \%$ & $20 \%$ & Relational, Servant, Modeling \\
\hline Crane-Lakeview K-12 & Central & $\mathrm{RR}$ & 130 & 3 & $70 \%$ & $20 \%$ & Relational, Servant \\
\hline Hillside K-8 & Central & $\mathrm{RR}$ & 110 & 4 & $50 \%$ & $10 \%$ & Modeling \\
\hline Eagle County HS & Central & $\mathrm{RR}$ & 40 & 1 & $40 \%$ & $10 \%$ & Modeling, Distributed \\
\hline Cardinal Jr.-Sr. HS & West & $\mathrm{RR}$ & 100 & 3 & $50 \%$ & $20 \%$ & Relational, Servant \\
\hline Wagner ES & Southeast & $\mathrm{RR}$ & 300 & 2 & $50 \%$ & $10 \%$ & Modeling, Distributed \\
\hline Green Lake Jr.-Sr. HS & Southeast & $\mathrm{RR}$ & 80 & 3 & $60 \%$ & $10 \%$ & Servant, Modeling \\
\hline Sharp ES & Southeast & $\mathrm{RR}$ & 300 & 3 & $50 \%$ & $10 \%$ & Modeling, Distributed \\
\hline Harris ES & Central & CL & 500 & 3 & $50 \%$ & $50 \%$ & Servant \\
\hline
\end{tabular}

$\mathrm{CL}=$ city, large; $\mathrm{CS}=$ city, small; $\mathrm{SM}=$ suburb, midsize; $\mathrm{TR}=$ town, remote; $\mathrm{RF}=$ rural, fringe; $\mathrm{RD}=$ rural distant; $\mathrm{RR}=$ rural, remote.

encountered: (a) difficulty in recruiting principals in the most remote region of the state, where many principals have nine-month contracts and were unavailable during the data collection period; (b) difficulty identifying schools with the highest accountability rating and FRPL rates above the state average.

\section{Data Collection}

Interview protocols were designed to cover a range of leadership topics, including principals' theories of leadership; vision, mission, and goals; barriers and challenges to meeting goals; high-quality instruction and instructional leadership practices; teacher evaluation; school improvement; and professional development and supports. The question used to elicit principals' implicit understandings of leadership used the word philosophy, rather than theory, in an attempt to evoke principals' understandings, rather than textbook answers about 
leadership theory. Interviews lasted between 30 and 60 minutes. All but one interview was conducted at the principals' school; the remaining interview was conducted via video conferencing software. To increase the validity of data collection, the second researcher received training on the protocol, including observing an interview and conducting an interview with the primary researcher. In both cases, a debriefing was used to discuss the protocol to increase understanding of the questions and adherence to the protocol (Guest et al., 2012). Note-taking and audio recording contributed to the accuracy of data (Kelly, 2013).

\section{Data Analysis}

Interviews were transcribed and uploaded into a Nvivo 10 databased. Data analysis began through the development of narratives from interviews, which were added to the dataset. Analysis of interviews utilized a mix of a priori codes developed from previous research on school leadership and themes identified in initial conversations between the researchers (Miles et al., 2014; Yin, 2014). A quarter of the transcripts were randomly selected for double coding. Each researcher independently conducted open coding on this subset of transcripts to generate initial categories. The researchers engaged in analytic conversations to create operational definitions of codes, select example quotes, and consolidate the codebook. The use of multiple coders and peer review reduces the bias of each researcher (Guest et al., 2012). Matrix displays (Miles et al., 2014) were used to examine connections between principals' theory of leadership and their reported instructional leadership practices.

\section{Findings}

This study examined principals' theories of leadership and their descriptions of their instructional leadership practices. We identified five theories of leadership, which principals either explicitly stated in answering questions about their philosophy of leadership, or implicitly in answering other questions about their school improvement and instructional leadership practices. These theories fell into five 
categories: relational leadership, leading by example, distributed leadership, servant leadership, and facilitative leadership. Most principals described at least two theories, suggesting school leaders draw on multiple schemas in carrying out leadership tasks. Principals described similar instructional leadership tasks; however, they appear to emphasize different aspects based on their schema. We present the findings below.

\section{Relational leadership}

Relational leadership was the most frequently described, with half of the sample identifying the importance of positive relationships. These principals described efforts to build trust and relationships with their teachers and what they referred to colloquially as "buy-in." For example, the principal of Green Lake ES, described this as getting the staff "behind you" and "building commonality" among teachers. She further described relationships as supporting commitment through trust, stating, "I think you have to build that relationship... I think the stronger you can have those relationships the easier that is to be a leader and to say I have faith in you, so now you have to have a little faith in me." She continued by linking her instructional leadership practice of walk-throughs to maintaining relationships and reducing competition:

When I do a walk-through, I leave comments. "Have you thought about this? Or you might want to talk to so-and-so, they've been trying this." I don't want to pair them up against each other so they think that one person is better than another, so I try not to do that either but I do try to say great things that everybody is doing all the time because they are -they're all doing super-good things.

The principal at urban Erikson HS, who reported that creating a positive climate contributed to "a sense of connection and belonging," echoed this sentiment. He also stated, "When that's not happening, it makes it more difficult for people to fully invest themselves." The principal of small city Clark City MS described his leadership as "building relationships," and stated, "I don't think you can go anywhere without building relationships with people, whether it's kids 
or whether that's adults, and then I think once you do that, half of the battle is already over." He also described collaborative decision-making as enabling change in his school, reporting, "Most of the time we make it [decisions] as a group and kind of figure out what's going to be best, and once you get that buy-in, then it's pretty easy to do some things." These things included innovative programming and instructional changes that he attributed to helping Clark City's largely immigrant and refugee students make significant academic growth.

Relational leaders frequently reported using walk-throughs as an instructional leadership strategy and identified affective concerns in delivering feedback from walkthroughs and formal observations. At Oak Springs ES, the principal stated, "I just don't score [the rubric] because I think there is a very fine line with the Marzano [rubric] of deflating a person where it feels hopeless and providing feedback where they feel like they're empowered to do something with it." This suggests she prioritized the emotional state of teachers and avoids reducing their self-efficacy. Likewise, the principal superintendent of rural, remote Crane-Lakeview $\mathrm{K}-12$ reported that as the sole administrator, he faced challenges in building relationships and providing feedback as teachers view him as the "boss." He reported, "I'd say that's the hardest one of leadership, is being able to build relationships and get that trusting relationship even though I am the boss." He continued, "If I just do a walk-through observation, and I want to give a suggestion, a teacher will feel threatened because it's coming from the superintendent." Relatively new to the district, he found this to be challenging due to his identification of the need to update the curriculum and instruction to match state standards and assessments.

\section{Leading by Example}

Approximately half of the principals in our study described their leadership as leading by example and modeling to set examples of the behaviors they wish to see from teachers. For example, at urban Erickson HS, the principal described himself as a "role model" who "sets a tone for my staff." This includes modeling social interactions and teaching practices to build teachers' capacity, which he described as, "My job is to help everybody be the best that can be so that they can help our students be the best they can be." At Wagner ES, the principal 
described the importance of modeling positive relationships, stating he does so to demonstrate to staff and students "that we care about relationships and about each other and we want to build upon that so that we can all become leaders."

Likewise, the principal at rural Hillside K-8 explicitly described her leadership theory as, "Leading by example and be[ing] willing to be right there alongside everyone, so if there's some initiative that you ought to do, or you foresee, you have to lead by example and be willing to put in the time." She provided an example of modeling in her instructional leadership by using "4-to-1s," or using four positive reinforcements to one critique, with her staff. Similarly, the principal at city small Oak Springs ES described modeling new practices, "I believe with any initiative, that if we are starting something new, I think it is absolutely my job to research that and to be a forerunner in that, that I am modeling exactly what I expect from every other staff member." She described this modeling as helping teachers to bridge the gap between where they are now and where she wants them to be. She provided the example of modeling expectations for how teachers treat children in a building that has experienced a significant demographic shift in recent years. She stated, "Kids will move heaven and earth for you if you are important to them. And so that was something I very much had to model with every child that came into our building, really taking an interest in them, loving them whether they came dirty...or whether their father was the lawyer... that every child is treated fairly and the expectation is the same." She reported that staff emulated her modeling of expectations for how to treat all students.

In addition to modeling instructional techniques and expectations for treating students, leading by example also included demonstrating a willingness to go above and beyond. The principal of rural Eagle County HS described this: “Don't ask someone to do something you are not willing to do yourself." The principal of rural Sharp ES stated, "There's not a job in my schools that I would not be the first to do and am not afraid to do. I think it's important for those that you are trying to lead to know that about you as a leader." Overall, principals who described their theory as leading by example used modeling to expectations for teachers' interactions with students and the use of instructional techniques, rolling up their sleeves to set an example. 


\section{Distributed Leadership}

Over a third of participants described their leadership as distributed, including both those in larger schools with formal leadership teams, and those in smaller schools with informal leadership roles. For example, at large urban Bernard HS, the principal reported relying on his leadership team of 12 individuals to provide instructional leadership to teachers and his role is to create shared messaging among them, stating, "They need to be able to have the same conversations that I have with the teachers so that we are all saying the same thing." Similarly, distributed leaders relied on teacher teams to engage in decision-making. At Clark City MS, the principal attributed innovation to teacher collaboration on committees and reported his commitment to shared decision-making and teamwork with teachers created "buy-in," or shared ownership of ideas co-created through collaboration, which in turn facilitated change and improvement. Similarly, the principal superintendent at rural Carleton ES reported that his teachers "feel ownership in everything" because of his commitment to collaboration and to taking input from teachers. He reported as a result, "[The teachers] have taken ownership in so many things that it's not something happening to them."

Principals also described building the capacity of teachers and empowering them to make decisions. For example, at rural Wagner ES, the principal reported, "I believe in shared leadership, where I empower teachers to become leaders so that my teachers become better no matter where they are at. So, including a leadership team within that." Likewise, at urban Jefferson MS, the principal reported he tries "to build capacity because there are so many things that need to be done and one person can't oversee everything that happens." He also described the need to "build capacity so people can make some of those decisions on their own."

Overall, principals who described themselves as using a distributed leadership theory spread decision-making tasks and instructional leadership to multiple members and teams, viewing their role as setting direction, but also building other's capacity to enact leadership. By doing so, they created teacher ownership of initiatives in their schools. 


\section{Servant Leadership}

Eight principals identified servant leadership, frequently using the phrase "servant leader" and words like "I serve" and "I provide." For example, the principal of urban Harris ES stated, "As an elementary principal, you are there to serve others, to serve your staff, serve your students, serve your families." In this high poverty urban school, the principal described the goal to be a full-service community school, working with students and families beyond the school bell. Within the school walls, she described her servant leadership as providing teachers with "good, authentic feedback and providing them with "resources and supports" so they can be "open and receptive to feedback."

Likewise, the principal at small town Midway ES stated, "I feel like my job is to support teachers to support kids.” He continued, "[I] try to provide them obviously basic materials, but also curriculum and direction and advice. I think part of my job is to make their job as good as it can be." Similarly, at rural Crane-Lake K-12, the principal superintendent stated, "I'm always there to support my teachers as much as possible. I've never said no to them, and I tell them that, like, when it comes to needs and wants in the classroom." He reported this included providing a variety of professional development opportunities. Servant instructional leaders emphasized working to provide support in instruction through authentic feedback, professional development, as well as the climate of the school. Servant leaders understood their roles as that of someone who supports the growth and development of the school and the community. The focus of this leadership theory is to bolster the work and lives of the people they serve.

\section{Facilitative Leadership}

Five principals described facilitative leadership, describing themselves as "consensus builders," working to create agreement and shared ownership among teachers. Facilitative leaders described themselves as guides who help teachers work through collective processes, such as school improvement planning. The principal at rural River View ES described her leadership as working alongside teachers to develop programming that fits the unique needs of her school, which includes a large population of Indigenous students: 
I don't believe in top-down I believe in side by side. I have learned a lot from the teachers that I work with. I try to bring them ideas and suggestions, but together we collaboratively develop it so that it fits our needs here locally. I like to push and hold people accountable and challenge ideas but I'm not a dictator and my way or the highway. I like it to be teacher-led primarily and I try to provide as much resources and insight and help and professional learning that is possible.

Likewise, principal superintendent of rural Carleton ES described his leadership as working toward agreement among teachers and the community, stating: "I'm not a top-down person. I'm a consensusbuilder, and I often try to work it out where I take [the] ideas of other people and make them happen... I'm not the owner/mover shaker of the whole thing. I really am a facilitator and consensus-maker." When asked for an example, he described, moving forward the board's vision of expanding prekindergarten programs and implementing a reading specialist's recommendation to increase phonics instruction.

Facilitative principals also reported serving as a guide for teachers' teams, such as the principal of urban Fairmont ES, who described guiding the school improvement team:

I am there as a sounding board and as a facilitator and as a guide, but I rarely say, "we are going to do this and we're all gonna do it." Just because, in my experience, that school improvement plan needs to be written and driven by teachers and measured by teachers. Otherwise, you get zero buy-in and people are like slopping their data on there just because it has to be done.

In this way, the principal of Fairmont avoided a compliance orientation toward school improvement and created a sense of shared ownership of the school vision, goals, and strategies to meet them. She also described the improvement plan as a living document to guide faculty meetings to discuss instruction and what teachers are doing to "achieve that common goal." 
Overall, facilitative leaders described themselves as guiding conversations about instruction and school improvement, seeking to build consensus and avoiding top-down mandates through democratic decision-making processes.

\section{Instructional Leadership}

Although principals espoused a variety of leadership theories, they identified similar instructional leadership tasks including professional development, coaching, collective goal setting, feedback from formal and informal walkthroughs, and instructional rounds and peer observation. However, they differed in how they described carrying out these practices. For example, relational principals prioritized building and maintaining relationships with teachers and between them. The principal at Green Lake ES described keeping her teachers' feelings in the forefront when giving feedback and trying not to "pit them against one another." The principal of East Side HS explained, "You can't micromanage them... you have to reassure them that you want them to be the very best teacher that they can be." Providing useful feedback was also seen as a way to build positive relationships with teachers. For example, the principal at rural Hillside K-8 stated, "Once they know that you have something to offer them and can give them valid feedback, I think you gained a good relationship because, at least our staff, they are always trying to be better." On the other hand, those who led by example appeared to prefer to model instructional practices for teachers.

Distributed leaderships spread instructional leadership across a variety of individuals. In larger schools, principals were able to distribute these instructional leadership tasks to assistant principals and instructional coaches. At Bernard HS, the principal distributed instructional leadership across a large team that provides coaching for teachers, which he described as "having actual conversations about what just happened...coaching is actually a deeply personal conversation." He described his role as ensuring coaches use the same vision of instruction. In smaller schools, distributed instructional leadership was more informal, such as at rural Riverview ES, where the principal superintendent reported freeing up the time of classroom teachers to "go in and observe other classrooms ... 
we have a coaching process that allows it to be a peer-driven feedback and support system." In this way, distributed leaders differed from servant leaders who tended to take sole ownership for instructional leadership tasks. Facilitative leaders tended to focus on group processes. The principal of Smith ES described his role as "making sure all of those groups are working and talking and collaborating." In these ways, principal leadership philosophies appear to serve as schema for instructional leadership tasks.

\section{Discussion}

Despite the importance of instructional leadership, questions remain as to the persistence of the gap between research knowledge and principal practice (Grissom et al., 2013; Shaked, 2018). This study contributes to the literature on school leadership in action by surfacing the implicit theories principals hold about their leadership and instructional leadership tasks, which have been identified as key areas to support teaching and learning (Robinson et al., 2008). Drawing from causal reasoning and social cognition theory (McCormick \& Martinko, 2004), implicit theories of leadership, and specifically leadership task schema, are theorized as contributing to the instructional leadership strategies and behaviors principals select in getting the conditions right for teaching and learning, which in turn influence student outcomes. These theories of leadership are seen as mental maps of "good" leadership (McCormick \& Martinko, 2004; Senge, 2006) that guide school leaders in their instructional leadership.

Our findings suggest that principals hold a variety of schema for school leadership, including relational, leading by example, distributed, servant, and facilitative leadership. A majority of the principals in this study described leadership that included aspects from across different leadership schema, suggesting principals engage different leadership maps for different tasks or goals using situational leadership to engage with the dynamics of each situation in deciding how to carry out tasks and make decisions (McCormick \& Martinko, 2004; Thompson \& Glasø, 2015). However, despite the variety in their schema, principals report engaging in many of the same leadership tasks, such as walkthroughs and feedback to teachers. 
Our findings also suggest a focus on the social aspects of school leadership. While principals described a variety of schema, a majority focused on positive interactions to generate investment and buyin on the part of teachers. For example, relational leaders, the largest group of principals in the study, reported consciously engaging in relationship building with teachers to generate trust that created support for their vision through social persuasion (Versland \& Erickson, 2017). For these principals, their schema of "a good principal" (McCormick \& Martinko, 2004) appeared to focus on trust and positive feedback as contributing to teacher commitment to shared goals. This leadership schema aligns with previous research that suggests relational leaders leverage positive relationships and trust to create consensus, motivation, commitment to the organization and shared goals (Zuckerman et al., 2017; Brower et al., 2000; Reitzug et al., 2008; UhlBien, 2006). Although previous research suggests trust and relationships are hallmarks of high performing schools (Tschannen-Moran \& Gareis, 2015), principals reported the importance of relationships and trust across accountability ratings.

Additionally, distributed and facilitative leaders appeared to focus on generating the commitment of teachers through collaborative goal-setting, decision-making, and problem-solving. Those who described distributing leadership identified assistant principals, coaches, and teachers as having leadership roles and engaging in instructional leadership. These leaders saw their role in part as building the capacity of others to take on leadership tasks. Similarly, facilitative leaders, saw themselves as guides in these processes, helping move others forward in collaboration and providing resources and learning opportunities. Previous research suggests such leadership strategies create space for collaboration and social learning, as well as increasing the capacity and commitment of teachers (Fullan \& Quinn, 2016; Leithwood \& Azah, 2017; Watt, 2009). Distributing of instructional leadership to those in both formal and informal roles, in particular, is seen as a means to increase the instructional capacity of teachers (Harris, 2008; Klar, 2012; Leithwood et al., 2004). Principals who described themselves as leading by example also engaged in social learning by modeling desired behaviors for teachers, while servant leaders focused on providing others with what they needed to be successful. 
Although previous research suggests principals frequently do not attend to instructional leadership due to time limitations or their understandings of the purpose of schooling (Grissom et al., 2013; Shaked, 2018), principals in this study, regardless of the theory of leadership described, identified similar instructional leadership tasks, such as walkthroughs and providing feedback to teachers. This suggests isomorphism in the educational system (Arum, 2000) created from external pressures such as accountability systems, intermediary organizations that provide training and resources to districts, and universities that provide preservice training. Yet, their approaches to these tasks differed, suggesting that leadership schema may have an impact not only on what leadership tasks principals engage in but also how they carry out those tasks.

\section{Conclusion}

The focus of ESSA on school leaders as a lever for improving education reflects the growing body of literature on the important, but often indirect roles principals, play in student success. Given the gap between research and practice in school leadership in practice, leadership schema, or mental maps of what it means to be a "good" school leader, may be a leverage point for bringing leadership in practice closer to best practices described in the literature. This study, undertaken to provide information about principals' approaches to leadership, identifies a variety of mental models, or schema, that leaders use to guide their practice. These included relational leadership, leading by example, distributed leadership, servant leadership, and facilitative leadership. Across the diverse schools in the sample, no clear pattern emerged between larger or small schools or those with different accountability ratings. This suggests a high degree of personal differences among school leaders, which raises more questions than it answers.

However, despite their variety of leadership schema, many reported using similar instructional leadership strategies, such as walkthroughs. Rather than choosing different instructional leadership tasks, schema appear to influence how they carry them out and what they focus on, such as relational leaders' focus on preserving positive 
relationships with teachers during feedback. This study raises questions about which approaches to instructional leadership tasks are most effective for student outcomes and school improvement, such as do differences in leadership schema impact the effectiveness of walkthroughs and feedback to teachers? How do principals' schema influence principals' efforts to maintain trust and positive relationships while leading teachers in instructional improvement? Likewise, given the lack of clear differences across school accountability categories, further research must clarify how various leadership schema influence the climate for teaching and learning, as well as student achievement.

Lastly, as for us as faculty in school leadership programs, this study raises questions about where principals receive messages about what it means to be a good leader, including preparation programs, in-service professional development, social networks, departments of education, and intermediary educational organizations. This study raises questions as to our own roles in crafting messages about good leadership, whether they are consistent throughout principals' preservice training, and how our programs contribute to school leaders' schema in ways that influence student achievement. Likewise, this study suggests a need to collectively craft coherence in messages to principals about leadership and expectations for high quality school leadership in ways that support instructional leadership to increase the impact of our efforts at improving principal practice as a lever for student achievement.

Conflicting Interests The authors declared no potential conflicts of interest with respect to the research, authorship, or publication of this article.

Funding This study was funded by the Nebraska Department of Education, Title II funds.

\section{References}

Arum, R. (2000). Schools and communities: Ecological and institutional dimensions. Annual Review of Sociology, 26(1), 395-418.

Baard, S. K., Rench, T. A., \& Kozlowski, S. W. (2014). Performance adaptation: A theoretical integration and review. Journal of Management, 4O(1), 48-99. 
Barbuto, J. E., Jr., \& Wheeler, D. W. (2006). Scale development and construct clarification of servant leadership. Group \& Organization Management, 31(3), 300-326.

Beattie, M. (2002). Educational leadership: Modeling, mentoring, making and remaking a learning community. European Journal of Teacher Education, 25(2-3), 199-221.

Black, G. L. (2010). Correlational analysis of servant leadership and school climate. Journal of Catholic Education, 13(4), 437-466. http://dx.doi. org/10.15365/joce.1304032013

Blase, J., \& Blase, J. (1996). Facilitative school leadership and teacher empowerment: Teacher's perspective. Social Psychology of Education, 1(2), 117-145.

Boiral, O., Talbot, D., \& Paillé, P. (2015). Leading by example: A model of organizational citizenship behavior for the environment. Business Strategy and the Environment, 24(6), 532-550.

Bolden, R. (2011). Distributed leadership in organizations: A review of theory and research. International Journal of Management Reviews, 13(3), 251-269.

Brower, H. H., Schoorman, F. D., \& Tan, H. H. (2000). A model of relational leadership: The integration of trust and leader-member exchange. Leadership Quarterly, 11(2), 227-250.

Cross, S. E., \& Markus, H. R. (1994). Self-schemas, possible selves, and competent performance. Journal of Educational Psychology, 86(3), 423-438.

Cunliffe, A. L., \& Eriksen, M. (2011). Relational leadership. Human Relations, 64(11), 1425-1449.

Cunningham, R. L. (2008). An examination of the relationship between servantleadership behavior of the elementary school principal, school climate and student achievement as measured by the 4th grade Mathematics and Reading Michigan Educational Assessment Program [Doctoral dissertation]. Eastern Michigan University. https://commons.emich.edu/cgi/viewcontent.cgi?article= $1138 \&$ context $=$ theses

Day, C., Jacobson, S. L., \& Johansson, O. (2011). Leading organizational learning and capacity building. In R. M. Ylimaki \& S. L. Jacobson (Eds.), US and crossnational policies, practices, and preparation (pp. 29-49). Springer.

Eisenkopf, G. (2020). Words and deeds-Experimental evidence on leading-byexample. The Leadership Quarterly, 31(4), 1-12.

Elmore, R. F. (2000). Building a new structure for school leadership. Albert Shanker Institute. https://files.eric.ed.gov/fulltext/ED546618.pdf

Entwisle, D. R., \& Astone, N. M. (1994). Some practical guidelines for measuring youth's race/ ethnicity and socioeconomic status. Child Development, 65(6), 1521-1540.

Eva, N., Robin, M., Sendjaya, S., Van Dierendonck, D., \& Liden, R. C. (2019). Servant leadership: A systematic review and call for future research. The Leadership Quarterly, 30(1), 111-132. 
Fletcher, J. K., \& Kaeufer, K. (2003). Shared leadership: Paradox and possibility. In C. Pearce \& J. Conger (Eds.), Shared leadership: Current thinking, future trends (pp. 21-47). SAGE Publications.

Fullan, M., \& Quinn, J. (2016). Coherence. Corwin Press.

Graham, S. (1991). A review of attribution theory in achievement contexts. Educational Psychology Review, 3(1), 5-39.

Greenleaf, R. (1970). The servant as leader. Robert K. Greenleaf Center.

Grissom, J. A., Loeb, S., \& Master, B. (2013). Effective instructional time use for school leaders: Longitudinal evidence from observations of principals. Educational Researcher, 42(8), 433-444.

Guest, G., MacQueen, K. M., \& Namey, E. E. (Eds.). (2012). Validity and reliability (credibility and dependability) in qualitative research and data analysis. In Applied thematic analysis (pp. 79-106). SAGE Publications.

Hallinger, P., Gümüş, S., \& Bellibaş, M. Ş. (2020). "Are principals instructional leaders yet?" A science map of the knowledge base on instructional leadership, 1940-2018. Scientometrics, 122(3), 1629-1650.

Hallinger, P., \& Murphy, J. F. (1985). Assessing the instructional management behavior of principals. The Elementary School Journal, 86(2), 217-247.

Hallinger, P., \& Murphy, J. F. (2013). Running on empty? Finding the time and capacity to lead learning. NASSP Bulletin, 97(1), 5-21.

Harris, A. (2008). Distributed leadership: According to the evidence. Journal of Educational Administration, 46(2), 172-188.

Harris, A., Leithwood, K., Day, C., Sammons, P., \& Hopkins, D. (2007). Distributed leadership and organizational change: Reviewing the evidence. Journal of Educational Change, 8(4), 337-347.

Heck, R. H., Larsen, T. J., \& Marcoulides, G. A. (1990). Instructional leadership and school achievement: Validation of a causal model. Educational Administration Quarterly, 26(2), 94-125.

Hord, S. (1992). Facilitative leadership: The imperative for change. Southwest Educational Development Laboratory. https://files.eric.ed.gov/fulltext/ ED370217.pdf

Kellar, F., \& Slayton, J. (2016). Fostering and achieving organizational change: A framework for studying the complexities of school leadership. Journal of School Leadership, 26(4), 690-715.

Kelly, S. E. (2013). Qualitative interviewing techniques and styles. In I. L. Bourgeault, R. De Vries, \& R. Dingwall (Eds.), The sage handbook of qualitative methods in health research (pp. 307-326). SAGE Publications. http:// sk.sagepub.com/reference/sage-hdbk-qualitative-methods-in-health-research/ $\underline{\mathrm{n} 17 . \mathrm{xml}}$

Klar, H. W. (2012). Fostering distributed instructional leadership: A sociocultural perspective of leadership development in urban high schools. Leadership and Policy in Schools, 11(4), 365-39o.

Lacroix, M., \& Verdorfer, A. P. (2017). Can servant leaders fuel the leadership fire? The relationship between servant leadership and followers' leadership avoidance. Administrative Sciences, 7(1), 6. 
Lawson, H. A., Durand, F. T., Wilcox, K. C., Gregory, K. M., Schiller, K. S., \& Zuckerman, S. J. (2017). The role of district and school leaders' trust and communications in the simultaneous implementation of innovative policies. Journal of School Leadership, 27(1), 31-67.

Leithwood, K. (2016). Department-head leadership for school improvement. Leadership and Policy in Schools, 15(2), 117-140.

Leithwood, K., \& Azah, V. N. (2017). Characteristics of high-performing school districts. Leadership and Policy in Schools, 16(1), 27-53.

Leithwood, K., Harris, A., \& Hopkins, D. (2008). Seven strong claims about successful school leadership. School Leadership and Management, 28(1), 27-42.

Leithwood, K., Louis, K. S., Anderson, S., \& Wahlstrom, K. (2004). Review of research: How leadership influences student learning. The Wallace Foundation.

Louis, K. S., Leithwood, K., Wahlstrom, K., \& Anderson, S. (2010). Investigating the links to improved student learning. Wallace Foundation.

Louis, K. S., Murphy, J., \& Smylie, M. (2016). Caring leadership in schools: Findings from exploratory analyses. Educational Administration Quarterly, 52(2), 310-348.

Martin, R., Guillaume, Y., Thomas, G., Lee, A., \& Epitropaki, O. (2016). Leadermember exchange (LMX) and performance: A meta-analytic review. Personnel Psychology, 69(1), 67-121.

McBrayer, J. S., Jackson, T., Pannell, S. S., Sorgen, C. H., De Blume, A. P. G., \& Melton, T. D. (2018). Balance of instructional and managerial tasks as it relates to school leaders' selfefficacy. Journal of School Leadership, 28(5), 596-617.

McCormick, M., \& Martinko, M. (2004). Identifying leader social cognitions: Integrating the causal reasoning perspective into social cognitive theory. Journal of Leadership and Organization Studies, 10(4), 2-11.

Metz, S., Piro, J. S., Nitowski, H., \& Cosentino, P. (2019). Transformational leadership: Perceptions of building-level leaders. Journal of School Leadership, 29(5), 389-408.

Miles, M. B., Huberman, A. M., \& Saldaña, J. (2014). Qualitative data analysis: A methods sourcebook. SAGE Publications.

Mireles-Rios, R., \& Becchio, J. A. (2018). The evaluation process, administrator feedback, and teacher self-efficacy. Journal of School Leadership, 28(4), $462-487$.

Neumerski, C. M. (2013). Rethinking instructional leadership, a review: What do we know about principal, teacher, and coach instructional leadership, and where should we go from here? Educational Administration Quarterly, 49(2), 310-347.

Price, H. E. (2012). Principal-teacher interactions: How affective relationships shape principal and teacher attitudes. Educational Administration Quarterly, 48(1), 39-85.

Price, H. E. (2015). School leadership in urban schools how social-relational leadership shapes teacher engagement. In M. Khalifa, N. Witherspoon Arnold, A. F. Osanloo, \& C. M. Grant (Eds.), Handbook of urban educational leadership (pp. 426-440). Rowman \& Littlefield. 
Qu, R., Janssen, O., \& Shi, K. (2015). Transformational leadership and follower creativity: The mediating role of follower relational identification and the moderating role of leader creativity expectations. The Leadership Quarterly, 26(2), 286-299.

Reitzug, U. C., West, D. L., \& Angel, R. (2008). Conceptualizing instructional leadership: The voices of principals. Education and Urban Society, 40(6), 694-714.

Robinson, V., Lloyd, C., \& Rowe, K. (2008). The impact of leadership on student outcomes: An analysis of the differential effects of leadership types. Educational Administration Quarterly, 44(5), 635-674.

Russell, R. F., \& Stone, G. A. (2002). A review of servant leadership attributes: Developing a practical model. Leadership \& Organization Development Journal, 23(3), 145-157.

Senge, P. M. (2006). The fifth discipline: The art and practice of the learning organization. Currency.

Shaked, H. (2018). Why principals sidestep instructional leadership: The disregarded question of schools' primary objective. Journal of School Leadership, 28(4), 517-538.

Shaw, J., \& Newton, J. (2014). Teacher retention and satisfaction with a servant leader as principal. Education, 135(1), 101-106.

Smylie, M. A., Mayrowetz, D., Murphy, J., \& Seashore Louis, K. (2007). Trust and the development of distributed leadership. Journal of School Leadership, 17(4), 469-503.

Spears, L. C. (2010). Character and servant leadership: Ten characteristics of effective, caring leaders. The Journal of Virtues \& Leadership, 1(1), 25-30.

Spillane, J. P., \& Burch, P. (2006). The institutional environment and instructional practice: Changing patterns of guidance and control in public education. In $\mathrm{H}$. D. Meyer \& B. Rowan (Eds.), The new institutionalism in education (pp. 87102). State University of New York Press.

Spillane, J. P., Halverson, R., \& Diamond, J. B. (2004). Towards a theory of leadership practice: A distributed perspective. Journal of Curriculum Studies, 36(1), 3-34.

Supovitz, J. A., \& Tognatta, N. (2013). The impact of distributed leadership on collaborative team decision making. Leadership and Policy in Schools, 12(2), 101-121.

Thompson, G., \& Glas $\varnothing$, L. (2015). Situational leadership theory: A test from three perspectives. Leadership \& Organization Development Journal, 36(5), 527-544.

Tschannen-Moran, M., \& Gareis, C. R. (2015). Faculty trust in the principal: An essential ingredient in high-performing schools. Journal of Educational Administration, 53(1), 66-92.

Uhl-Bien, M. (2006). Relational Leadership Theory: Exploring the social processes of leadership and organizing. The Leadership Quarterly, 17(6), 654-676.

Urick, A. (2016). Examining US principal perception of multiple leadership styles used to practice shared instructional leadership. Journal of Educational Administration, 54(2), 152-172. 
(2011). Servant leadership: A review and synthesis. Journal of Management, 37(4), 1228-1261.

Versland, T. M., \& Erickson, J. L. (2017). Leading by example: A case study of the influence of principal self-efficacy on collective efficacy. Cogent Education, 4(1), 1-17.

L., \& Louis, K. S. (2008). How teachers experience principal leadership: The roles of professional community, trust, efficacy, and shared responsibility. Educational Administration Quarterly, 44(4), 458-495.

Watt, W. M. (2009). Facilitative social change leadership theory: 10 recommendations towards effective leadership. Journal of Leadership Education, 8(2), 50-71.

Yin, R. K. (2014). Case study research: Design and methods. SAGE Publications.

Yin, H., \& Schmeidler, P. J. (2009). Why do standardized ISO 14001 environmental management systems lead to heterogeneous environmental outcomes?

Business Strategy and the Environment, 18(7), 469-486.

Zuckerman, S. J., Wilcox, K. C., Durand, F. T., Lawson, H. A., \& Schiller, K. S. (2017). Drivers for Change: A Study of Distributed Leadership and Performance Adaptation during Policy Innovation Implementation. Leadership and Policy in Schools, 17(4), 618-646.

\section{*}

\section{About the authors}

Sarah J. Zuckerman is an assistant professor of Educational Administration at the University of Nebraska-Lincoln. She is a former special education teacher, serving in rural and urban schools. Her research uses qualitative methods to investigate school and district leadership state-level educational policy implementation and partnerships. Her recent research combines organizational change theory with concepts from political science to understand how individuals, groups, and organizations mobilize and develop shared understandings that shape action at the school, community, and state policy levels.

Cailen O'Shea is an assistant professor of educational and organizational leadership at North Dakota State University. His research interests focus on school transformation and what educational leaders can do to enhance their instruction for underserved populations. Previously, Dr. O'Shea served as a behavior interventionist, 5th-grade teacher, and instructional technology coach in two Title I schools in Lincoln, Nebraska 